\title{
Surface-Mining Modeling for USGS Coal Assessments
}

Open-File Report 2021-1059 



\section{Surface-Mining Modeling for USGS Coal Assessments}

By Paul E. Pierce

Open-File Report 2021-1059 


\section{U.S. Geological Survey, Reston, Virginia: 2021}

For more information on the USGS - the Federal source for science about the Earth, its natural and living resources, natural hazards, and the environment—visit https://www.usgs.gov or call 1-888-ASK-USGS.

For an overview of USGS information products, including maps, imagery, and publications, visit https://store.usgs.gov/.

Any use of trade, firm, or product names is for descriptive purposes only and does not imply endorsement by the U.S. Government.

Although this information product, for the most part, is in the public domain, it also may contain copyrighted materials as noted in the text. Permission to reproduce copyrighted items must be secured from the copyright owner.

Suggested citation:

Pierce, P.E., 2021, Surface-mining modeling for USGS coal assessments: U.S. Geological Survey Open-File Report 2021-1059, 13 p., https://doi.org/10.3133/ofr20211059.

ISSN 2331-1258 (online) 


\section{Contents}

Abstract

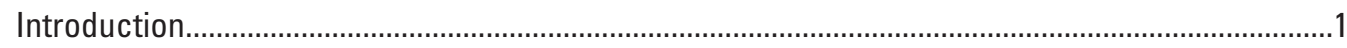

Surface Mining Operations Used in USGS Coal Assessments ......................................................

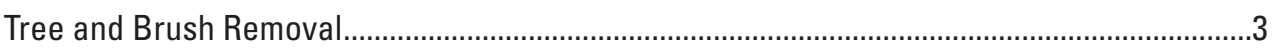

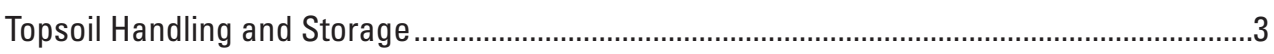

Overburden Drilling and Blasting .....................................................................................

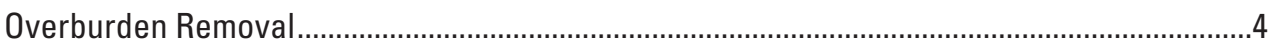

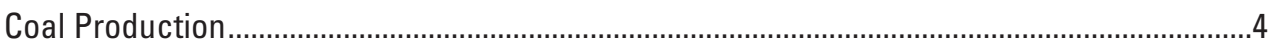

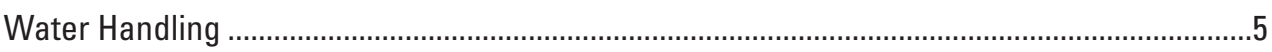

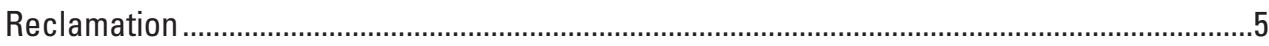

Surface Facilities Required for USGS Surface-Mining Model....................................................

Economic Modeling of USGS Surface Coal Mining Operations ..........................................................

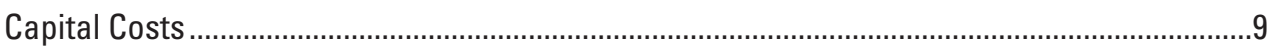

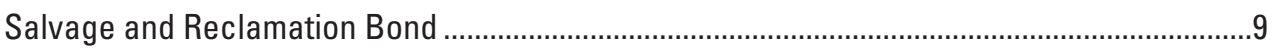

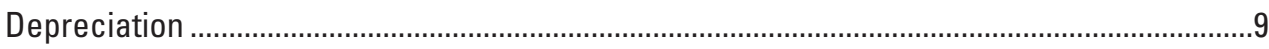

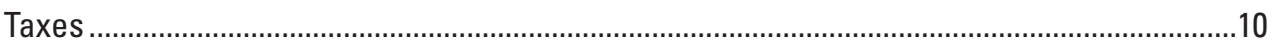

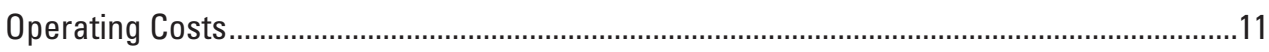

Income: Coal Sales Based on Market Price Calculation ..........................................................11

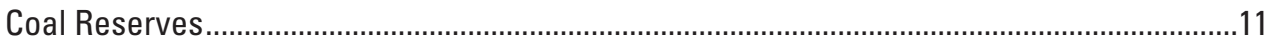

Future Coal Assessment Studies .............................................................................................

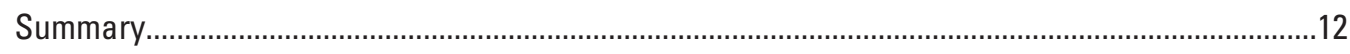

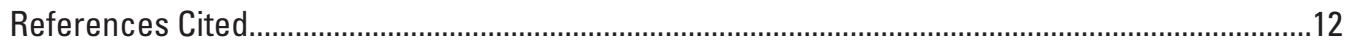

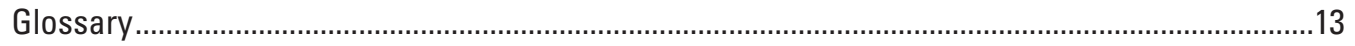

\section{Figures}

1. Flow chart for the classification of coal resources and reserves used by the U.S. Geological Survey for coal assessment studies ...........................................................

2. Plan view of a surface mine layout showing strip-mining methods .................................

3. Schematic drawing of a surface mine using strip-mining methodology showing

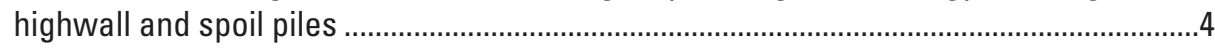

4. Photographs of surface strip-mining operation. $A$, dragline removes overburden above a coal bed. $B$, highwall with a coal bed at its base. $C$, spoil piles ......5

5. Schematic drawing of a surface mine using bench strip-mining methodology ...............6

6. Flow chart showing single bench surface-mining operations ...........................................

7. Flow chart showing double bench surface-mining operations .........................................7

8. Schematic view of a strip pit that shows blasthole drilling and the layout of the blasthole pattern .........................................................................................................

9. Photograph of a surface strip mine area that has been reclaimed to grassland .............8 


\section{Tables}

1. Order and description of operations used in surface strip mining method ......................6

2. Cost calculation for hypothetical surface mining operation to determine breakeven point between sales price and mining cost

\section{Conversion Factors}

U.S. customary units to International System of Units

\begin{tabular}{lcl}
\hline \multicolumn{1}{c}{ Multiply } & By & To obtain \\
\hline foot $(\mathrm{ft})$ & Length & \\
\hline & 0.3048 & meter $(\mathrm{m})$ \\
\hline pound, avoirdupois $(\mathrm{lb})$ & Mass & \\
ton, short $(2,000 \mathrm{lb})$ & 0.4536 & kilogram $(\mathrm{kg})$ \\
British thermal unit per pound (Btu/lb) & 0.9072 & metric ton $(\mathrm{t})$ \\
\hline
\end{tabular}

Temperature in degrees Celsius $\left({ }^{\circ} \mathrm{C}\right)$ may be converted to degrees Fahrenheit $\left({ }^{\circ} \mathrm{F}\right)$ as follows: ${ }^{\circ} \mathrm{F}=\left(1.8 \times{ }^{\circ} \mathrm{C}\right)+32$.

Temperature in degrees Fahrenheit $\left({ }^{\circ} \mathrm{F}\right)$ may be converted to degrees Celsius $\left({ }^{\circ} \mathrm{C}\right)$ as follows: ${ }^{\circ} \mathrm{C}=\left({ }^{\circ} \mathrm{F}-32\right) / 1.8$. 


\title{
Surface-Mining Modeling for USGS Coal Assessments
}

\author{
By Paul E. Pierce
}

\begin{abstract}
The value of national coal deposits is determined for the Solid Fuel Energy Resources Assessment and Research Project through economic evaluations using hypothetical mining models. Deposits near the surface are evaluated with the U.S. Geological Survey (USGS) surface-mining model, which is patterned after the standard mining techniques and infrastructures of commercial mining projects. The USGS surface-mining model uses these commercial mining project techniques as guides to develop a quantitative measurement to distinguish between potential recoverable resources and reserves by comparing total project cost and market value.
\end{abstract}

\section{Introduction}

This report describes the elements of the U.S. Geological Survey (USGS) surface-mining model and calculations used in coal assessments to determine reserve potential from estimated recoverable coal resources. Coal deposit assessments on public lands have been a long-term project of the USGS and will allow the USGS to identify and classify the economic potential of coal resources as described in a coal resources classification flowsheet (fig. 1).

The classification of coal resources as reserves is based on the profitability of the coal when comparing the estimated cost of extraction to the projected sales price of the coal product. An economic breakeven point is established in cases where the cost of extraction per ton of coal is equal to the per ton sales price. Coal resources are classified as reserves when the cost of extraction is less than the sales price of the coal, and a profit can be realized when extracting the coal. When the estimated cost of extraction is greater than the projected sales price of the coal, the coal remains classified as a recoverable resource. In coal mining models used by the USGS, the extraction cost is based on the freight on board cost at the mine prior to the addition of any shipping or other handling costs.

This report describes the USGS surface-mining model for near-surface coal beds typically lying within 200 feet (ft) of the surface (Luppens and others, 2008) but with depth variations depending on regional surface-mining analogs. Mine modeling is part of a collaborative process that is integrated with geological models, environmental and societal restrictions, technical limitations, and economic analyses to delineate reserves from recoverable resources.

\section{Surface Mining Operations Used in USGS Coal Assessments}

The surface-mining model depends upon processes that expose and extract coal in near-surface deposits using largescale mechanized excavations, typically by strip mining or other open-pit methods. Strip mining is the most common surface mining method used to extract coal in the United States and is the primary method used for coal valuation in the USGS surface-mining model. In this method, coal is exposed when overlying rock (called overburden) is stripped away leaving long, narrow, open trenches (also known as pits). The exposed coal is removed from the pit while stripping away overburden material continuing to lengthen the pit laterally. When the stripping operation reaches the projected lateral limit of the pit, it reverses course and creates a new pit adjacent to and parallel with the old pit (fig. 2). Each pit is backfilled with the spoils (broken overburden) of the previous pit. The excavation of the pit creates a near-vertical escarpment (or highwall) along the unmined overburden adjacent to the pit and a row of spoil piles on the mined side (fig. 3). A dragline machine (fig. $4 A$ ) digs the pit forming the highwall (fig. $4 B$ ) and spoil piles (fig. $4 C$ ). The highwall remains after the excavation of the pit until the dragline reverses, excavates a new pit, and removes the old highwall. The strength highwall (as shown in the top and middle photographs) usually determines its angle of inclination.

Multiple coal beds may also be strip mined using bench mining methods (fig. 5). For recovery of the top coal bed, overburden is stripped and dumped in a spoil pile. Then, the top coal bed is extracted, interburden is stripped and dumped onto the spoil pile, and the bottom coal bed is extracted. The principal steps for surface strip mining methods are described below and outlined in table 1 . The sequential operations for both single-bed and multiple-bed assessments are shown in figures 6 and 7, respectively, and described below. 


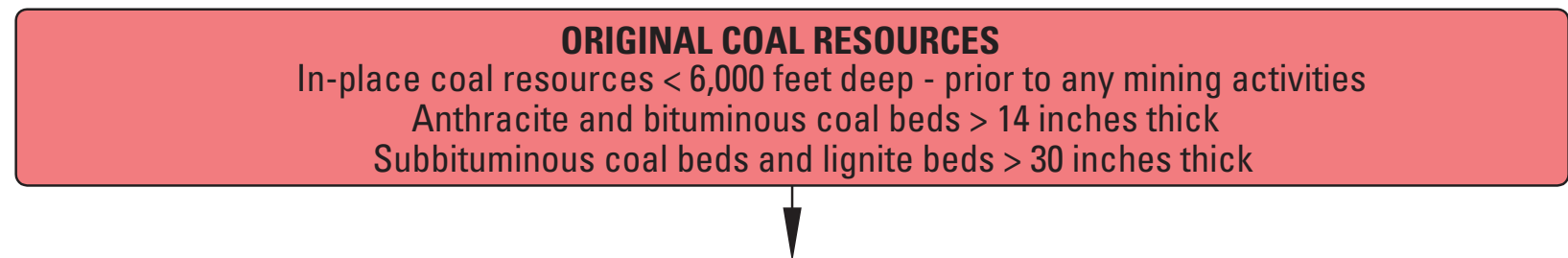

SUBTRACT: coal resources that have been previously extracted and coal resources left as pillars, barriers, or sterilized by previous mining activities.

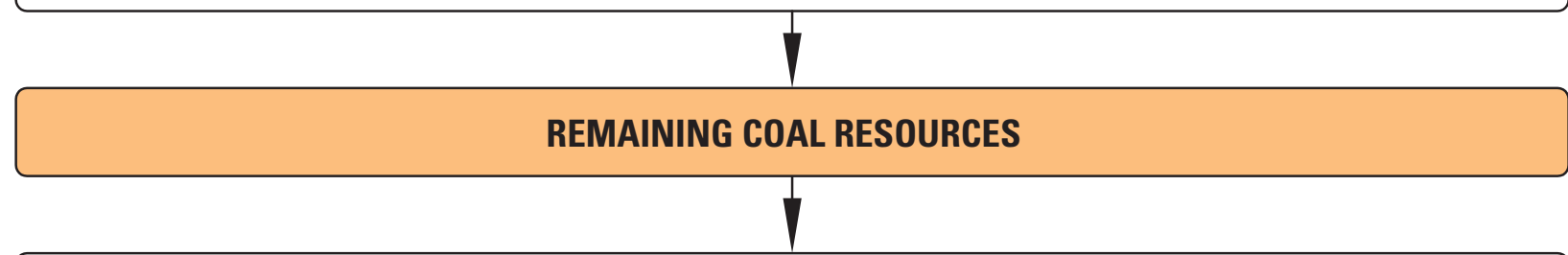

SUBTRACT: coal resources lost due to land use, environmental, or societal restrictions.

SUBTRACT: coal resources not extractable due to weathering, excessive depths of cover, high stripping ratios, being too thick or thin, geological anomalies, or other technical or mining limitations.

\section{AVAILABLE COAL RESOURCES}

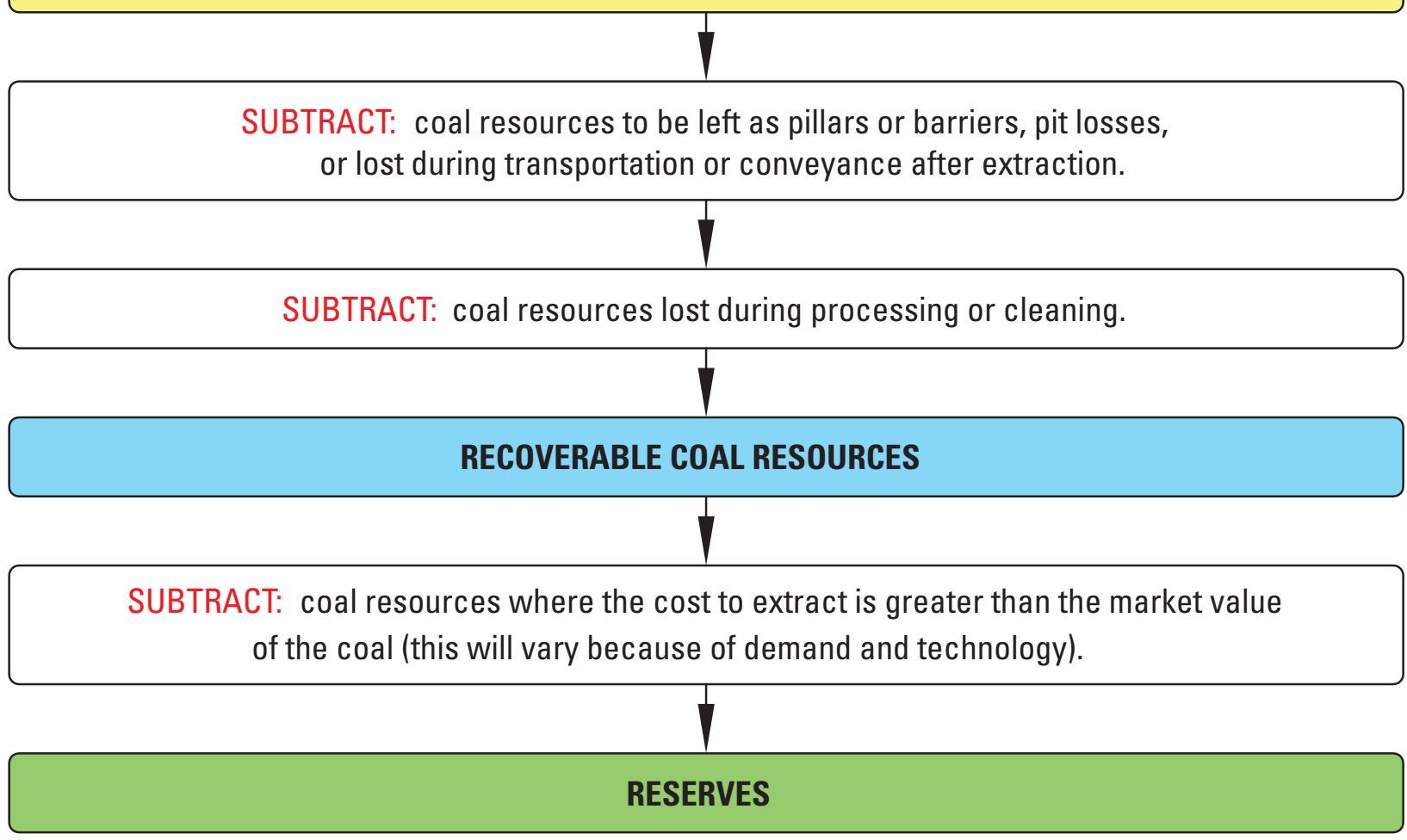

Figure 1. Classification of coal resources and reserves used by the U.S. Geological Survey for coal assessment studies (Luppens and others, 2009). 

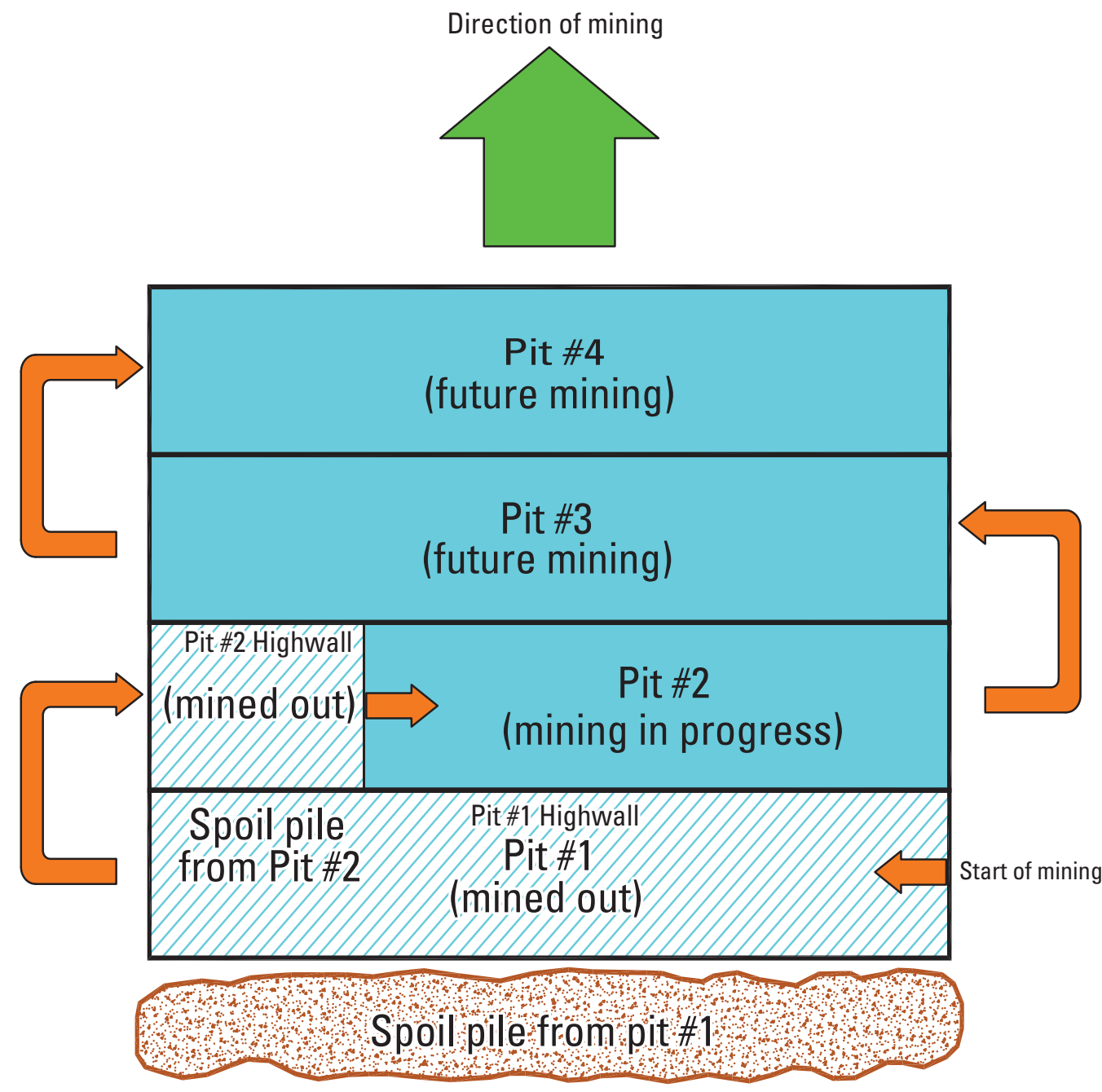

Figure 2. Plan view of a surface mine layout showing strip-mining methods. (\#, number).

\section{Tree and Brush Removal}

Prior to stripping operations, dozers remove vegetation and debris from the mining site. Vegetation can include trees of all sizes, in addition to brush and grass. Rocks and other debris are removed as well. Once the removal process is finished, only bare ground remains, and topsoil is exposed. Associated costs in the surface-mining model include equipment purchases and operational expenses.

\section{Topsoil Handling and Storage}

Topsoil can compose the first few inches or several feet of soil. It is removed and stored for use in reestablishing vegetation following mining. Undisturbed topsoil retains the nutrients necessary to support existing plant life, while deeper soils are often sterile and unproductive. Topsoil is a valuable commodity that helps assure that a mine site can be revegetated to established environmental standards and regulations after strip mining has been completed.
Large scraper machines are often the primary movers of topsoil. To begin topsoil removal, these machines' trailer bodies are lowered and cut into the earth. Soil enters the trailer body as a scraper moves forward and, when full, the trailer body is raised and the scraper drives to a storage pile. Dozers may assist by pushing the scraper as it is loading. A dozer or grader with rear-mounted ripper teeth may also assist by first breaking the soil for easier loading. At the storage pile, the scraper lowers the rear of its trailer body and topsoil flows out into a long narrow pile. Another dozer or grader may follow to smooth the surface of the pile into a gently sloping profile. Topsoil may be stored in piles for a few months to several years before it is returned as part of the reclamation of disturbed land. The costs associated with machine operations for this step are included in the mining model. 


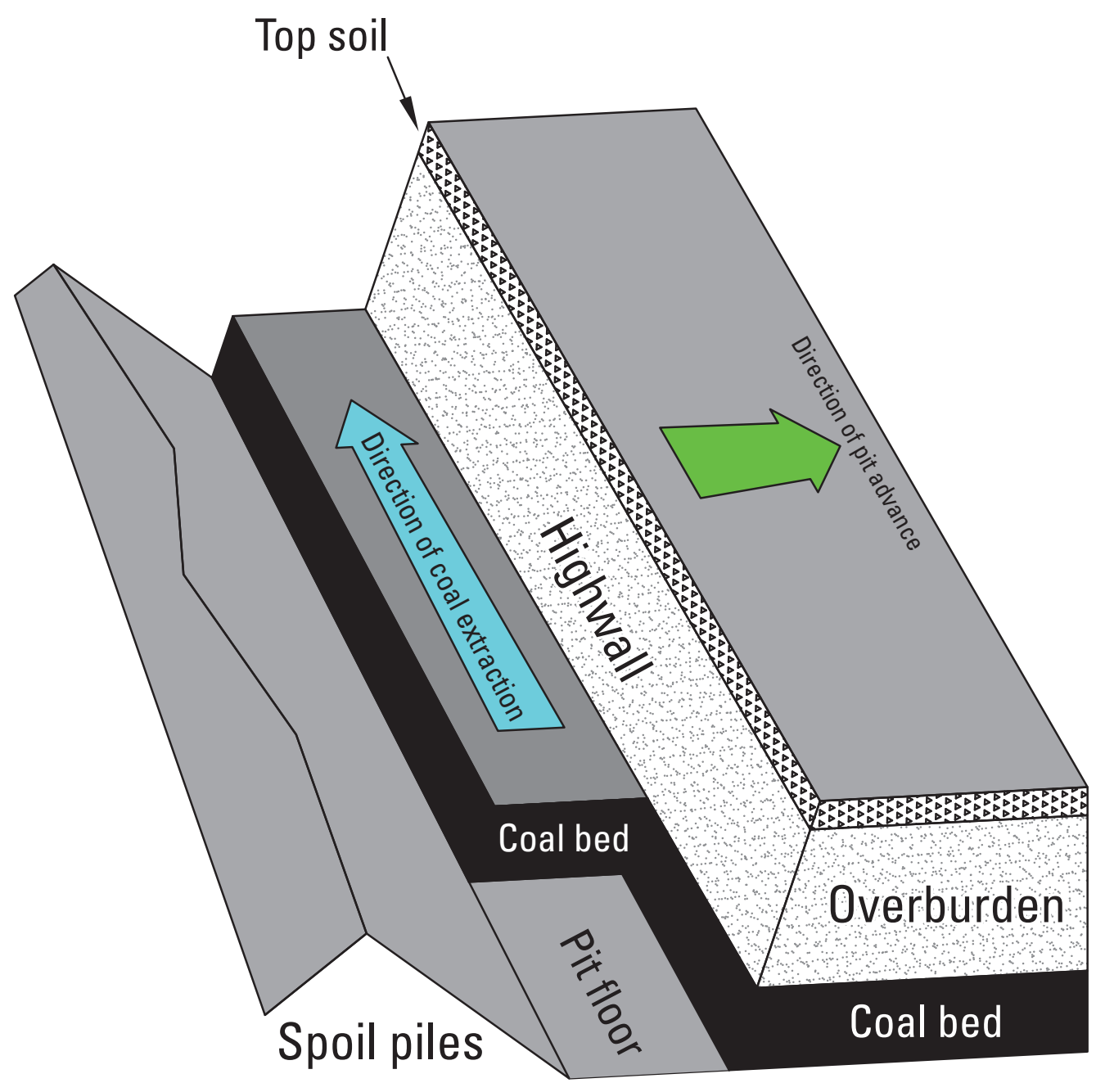

Figure 3. Surface mine using strip-mining methodology showing highwall and spoil piles.

\section{Overburden Drilling and Blasting}

Solid rock in the overburden (below the topsoil) is broken and heaved by explosives to facilitate easier removal. Blastholes are drilled in rectangular, evenly spaced patterns to the entire depth of the overburden. In some cases, blast holes are drilled slightly lower (fig. 8). Blastholes may be vertical or inclined and are partially loaded with an explosive that is typically an ammonium nitrate/fuel oil mixture (ANFO). A stemming of sand or drill-hole cuttings are poured on top of the explosive. The stemming provides a momentary blockage that directs most of the blast energy laterally into the rock mass and not out the top of the hole. Interburden is blasted using similar techniques.

Drilling and blasting costs include the drill (machine, bit, and rods), an explosives truck, blasting supplies (ANFO, electric delay caps, and lead wires), and personnel (driller, driller helper, shotfirer, and blaster helper).

\section{Overburden Removal}

A variety of loader types may be used to remove overburden and interburden. Appropriate loaders can remove material from the toe of a bench or highwall to its crest in a single pass. The largest models of rubber-tired (front-end) loaders can remove overburden up to $40 \mathrm{ft}$ thick, cable shovels up to about $60 \mathrm{ft}$ thick, and draglines up to about $180 \mathrm{ft}$ thick. Dozers may assist in overburden removal by collapsing embankments and pushing loose overburden for easier removal. The number and sizes of necessary excavating equipment are calculated from overburden removal amounts in the mining model to determine their cost.

\section{Coal Production}

Coal extraction is often performed by rubber-tired loaders. In figure $4 A$, a rubber-tired loader is positioned between haulage trucks below the dragline and atop the exposed coal. 
$\boldsymbol{A}$

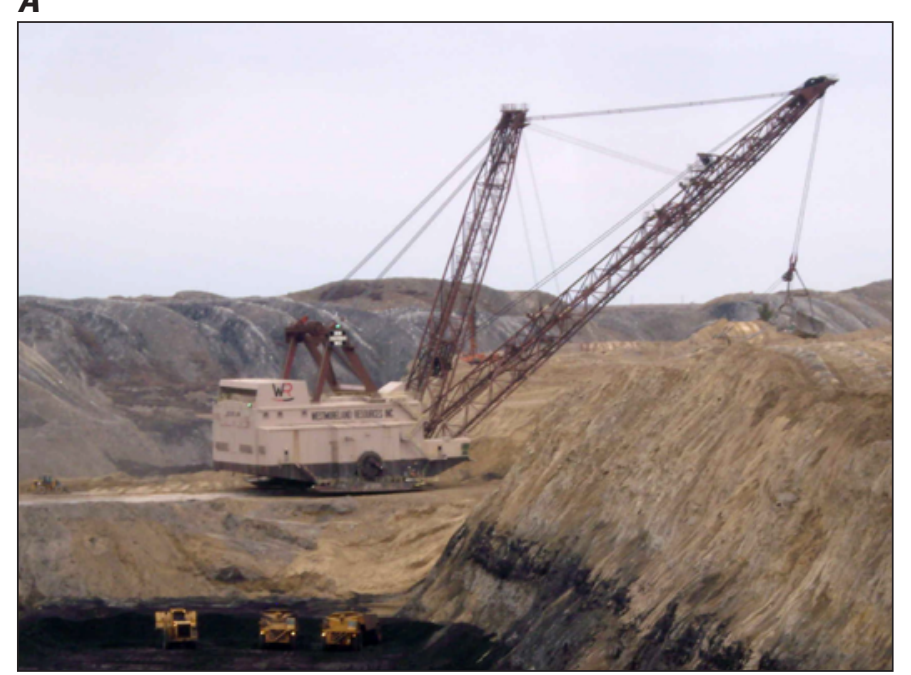

B

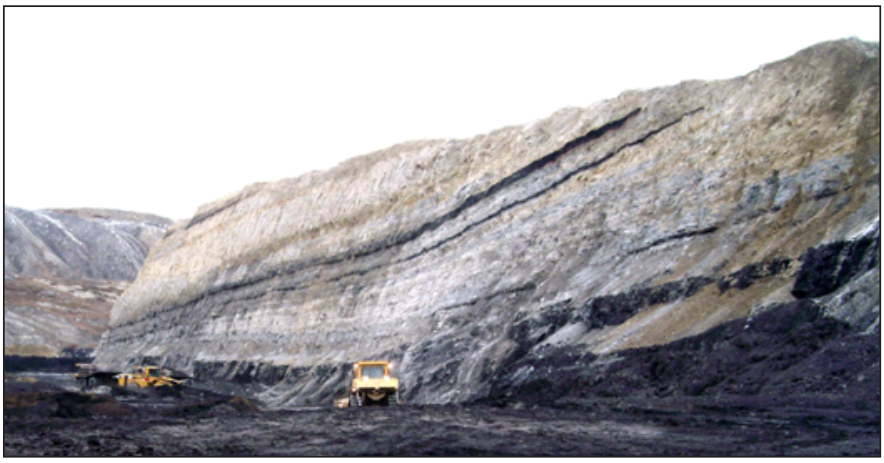

C

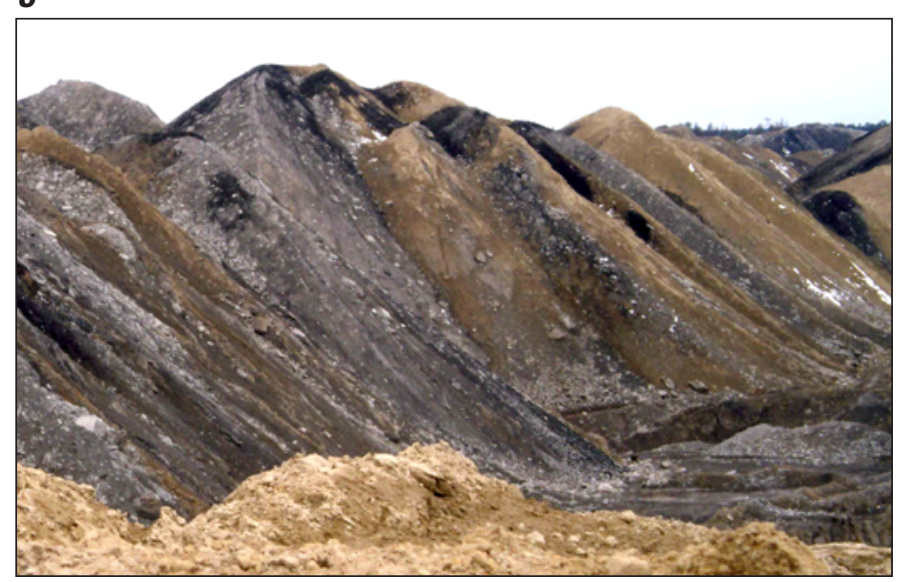

Figure 4. Surface strip-mining operation. $A$, dragline removes overburden above a coal bed. $B$, highwall with a coal bed at its base. $C$, spoil piles. All photographs by Paul Pierce, U.S. Geological Survey.
In the photograph, one truck is being loaded while another waits. Haulage trucks and loaders are matched by volume for cost-effective fleet size. The coal in figure $4 A$ was previously broken by dozer-mounted rippers. The dozer piles coal so that the rubber-tired loader can easily load multiple haulage trucks. Loaders are sized according to the loose volume of the coal. Mining costs for loaders and haulage trucks include their purchase, replacement, operation (fuel, lubrication, maintenance, and tires), and personnel (salaries and benefits) are included in the mining model.

\section{Water Handling}

Groundwater and stormwater are collected in temporary sumps hollowed in low portions of the pit floor. Sumps are typically made by a dozer performing various in-pit functions. To remove water from these sumps, a pump discharges into water trucks for removal from the pit. An added benefit to the water collection is its spraying on haulage roads for improved compaction and dust control. In addition, stormwater flow may be collected outside of the pit and channeled away from in-pit operations. Only pump purchases are included in mining costs for this step. Water trucks are included in the mining model with other general-use equipment as part of mine facilities.

\section{Reclamation}

The reclamation step entails restoring areas where mining operations have been completed. During reclamation, spoil piles are recontoured to match the original lay of the land and the stored topsoil is placed on the recontoured spoil. Vegetation may be reestablished as grassland (fig. 9). Land restoration attempts to recreate premining conditions unless new conditions are negotiated with various stakeholders. Reclamation is an ongoing activity where mining operations have been completed.

Revegetation is a seasonal operation. It may lag well behind recontouring spoil piles until replanting can be conducted. During replanting, a farm tractor breaks the soil; prepares the seed bed; and plants with spring tooth, disc, and seeder equipment. Grassland may be reestablished with a combination of native grasses and legumes selected for their hardiness. The cost of reclamation also includes the planting of tree sprigs. Reclamation is performed as an operating expense and is included in the overall operating cost in the mining model. 
Table 1. Order and description of operations used in surface strip mining method.

\begin{tabular}{|c|c|c|}
\hline Operation & Equipment used & Description of activities \\
\hline Brush removal & Dozer & Trees and brush are uprooted and collected for disposal. \\
\hline Topsoil removal and storage & $\begin{array}{l}\text { Dozer } \\
\text { Scraper }\end{array}$ & Topsoil is ripped, loaded, and hauled to stockpile for storage. \\
\hline Overburden drilling and blasting & $\begin{array}{l}\text { Drill rig } \\
\quad \text { Explosives truck }\end{array}$ & $\begin{array}{l}\text { Blast holes are drilled above highwall, loaded with explosives, and deto- } \\
\text { nated. }\end{array}$ \\
\hline Highwall cleanup & Dozer & $\begin{array}{l}\text { Crest of highwall is trimmed of loose rock. } \\
\text { Coal berm is pushed against toe of highwall. }\end{array}$ \\
\hline Water handling in pit & $\begin{array}{l}\text { Dozer } \\
\text { Submersible pumps } \\
\text { Water tanker }\end{array}$ & $\begin{array}{l}\text { Rough-hewn sumps are excavated along toe of highwall. Collected storm- } \\
\text { water is pumped into water tanker for road dust suppression. }\end{array}$ \\
\hline Coal loading & $\begin{array}{l}\text { Loader } \\
\text { Haul trucks }\end{array}$ & $\begin{array}{l}\text { Coal is loaded and transported to coal-processing facility for crushing, } \\
\text { optional cleaning, storage, and shipment. }\end{array}$ \\
\hline Spoil pile recontouring & $\begin{array}{l}\text { Dozer } \\
\text { Grader }\end{array}$ & $\begin{array}{l}\text { Spoil piles are leveled and recontoured to original terrain profile. Final pit } \\
\text { is backfilled. }\end{array}$ \\
\hline Topsoil replacement & $\begin{array}{l}\text { Grader } \\
\text { Scraper }\end{array}$ & $\begin{array}{l}\text { Stored topsoil is transported from stockpile and spread evenly over recon- } \\
\text { toured spoil. }\end{array}$ \\
\hline Revegetation & $\begin{array}{l}\text { Farm tractor } \\
\text { Farm implements } \\
\text { Utility truck }\end{array}$ & $\begin{array}{l}\text { Reestablished topsoil is reseeded with grasses and forbs and mulched. Trees } \\
\text { may be planted in appropriate areas. }\end{array}$ \\
\hline
\end{tabular}

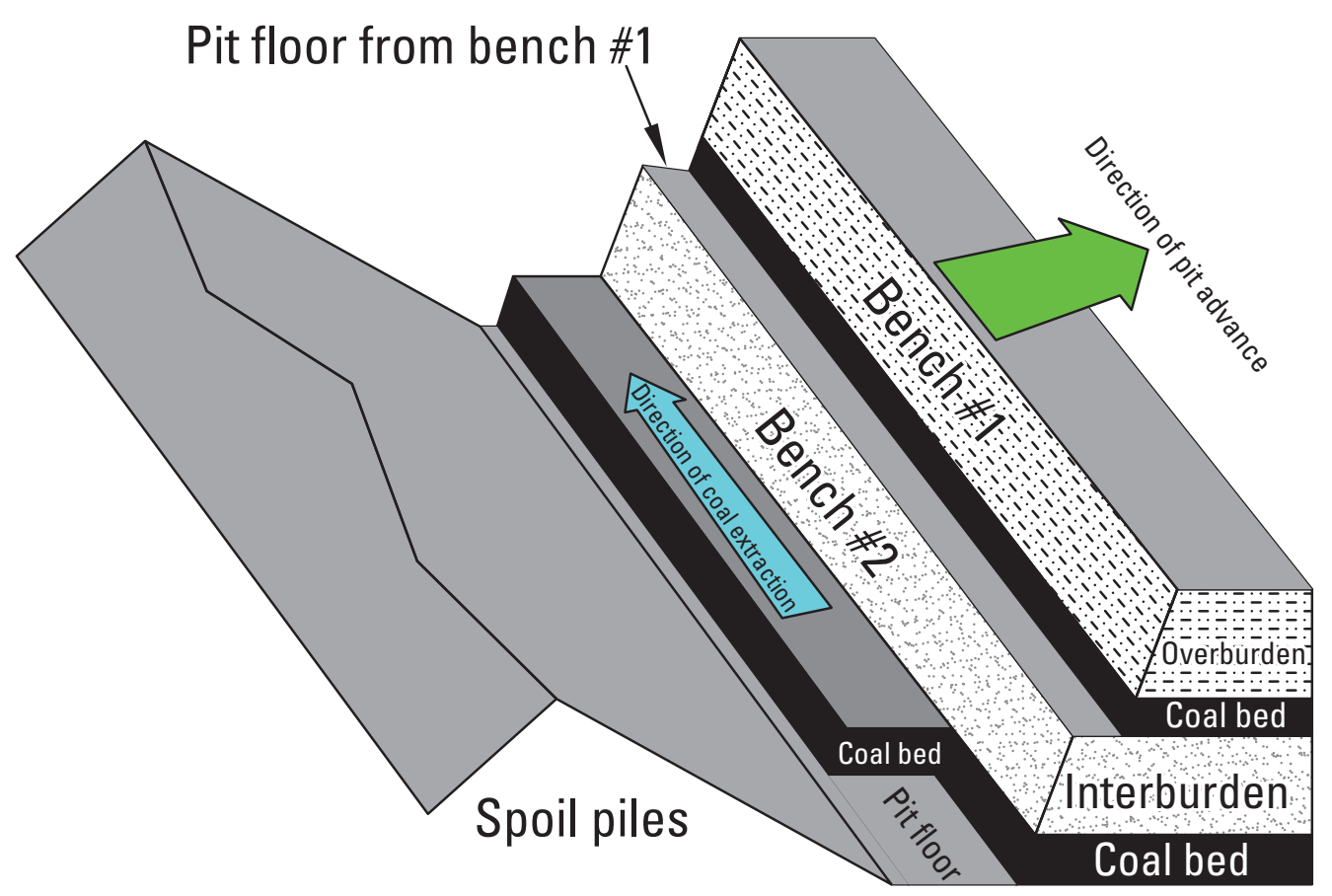

Figure 5. Surface mine using bench strip-mining methodology. (\#, number). 

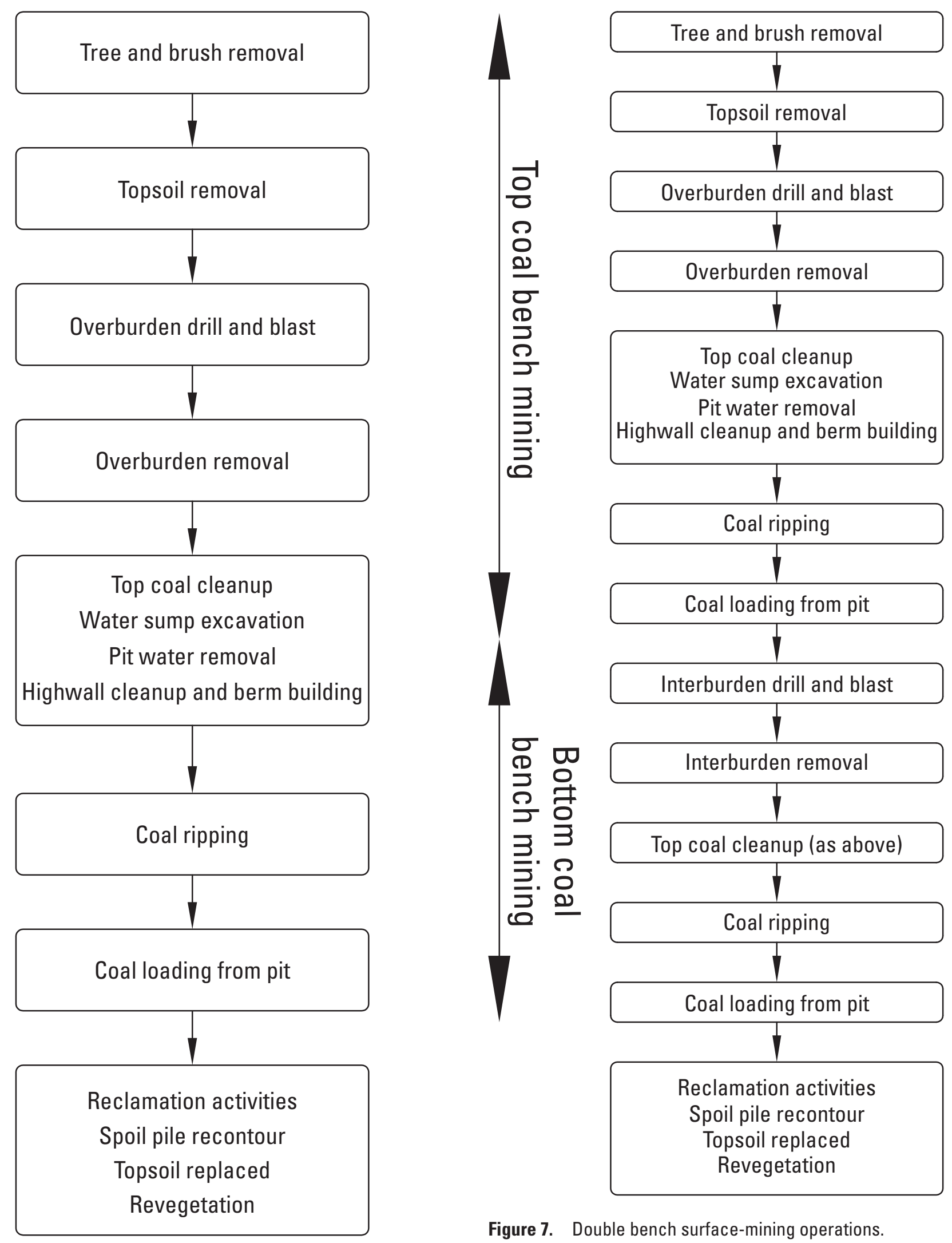

Figure 7. Double bench surface-mining operations.

Figure 6. Single bench surface-mining operations. 


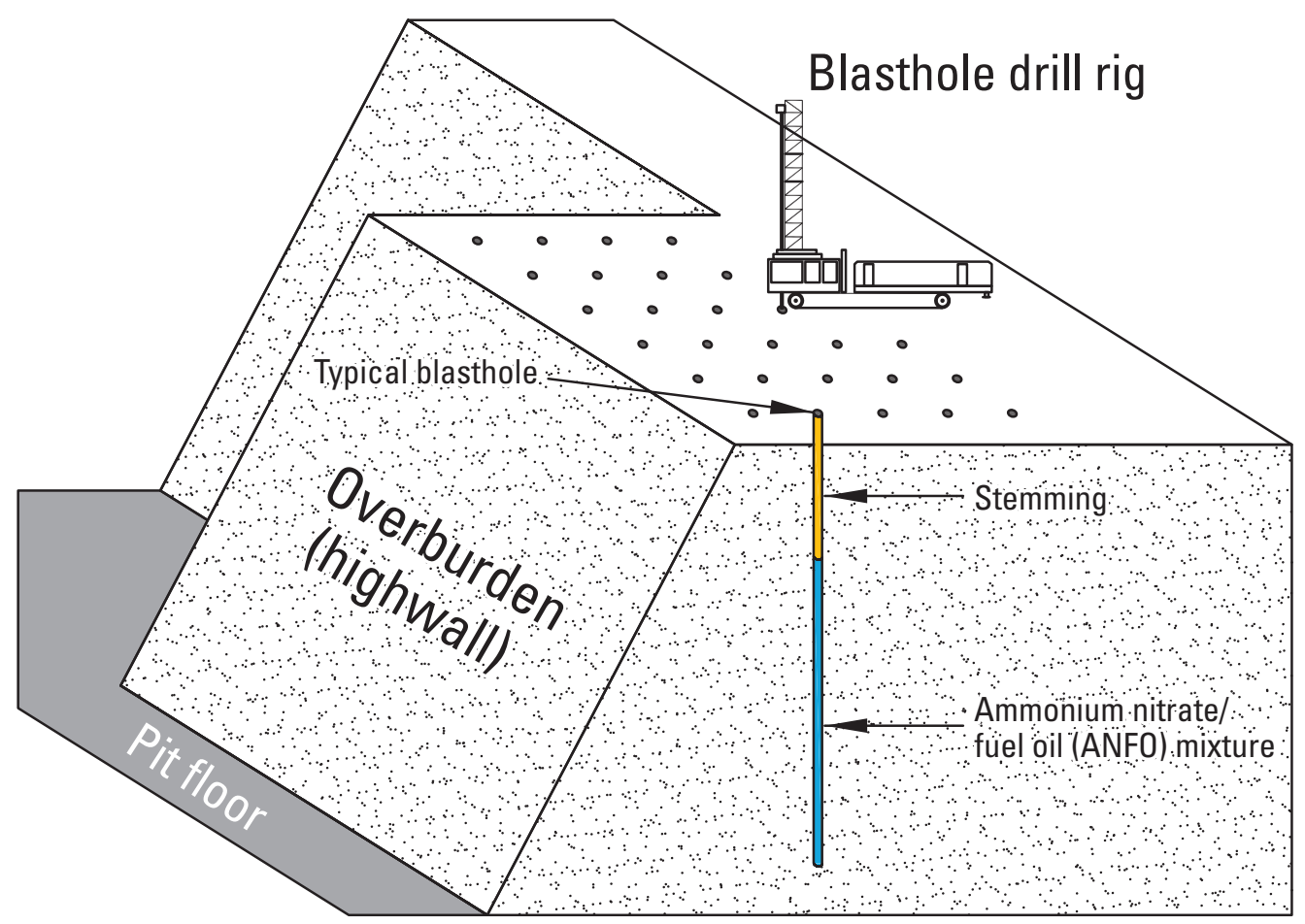

Figure 8. Schematic view of a strip pit that shows blasthole drilling and the layout of the blasthole pattern.

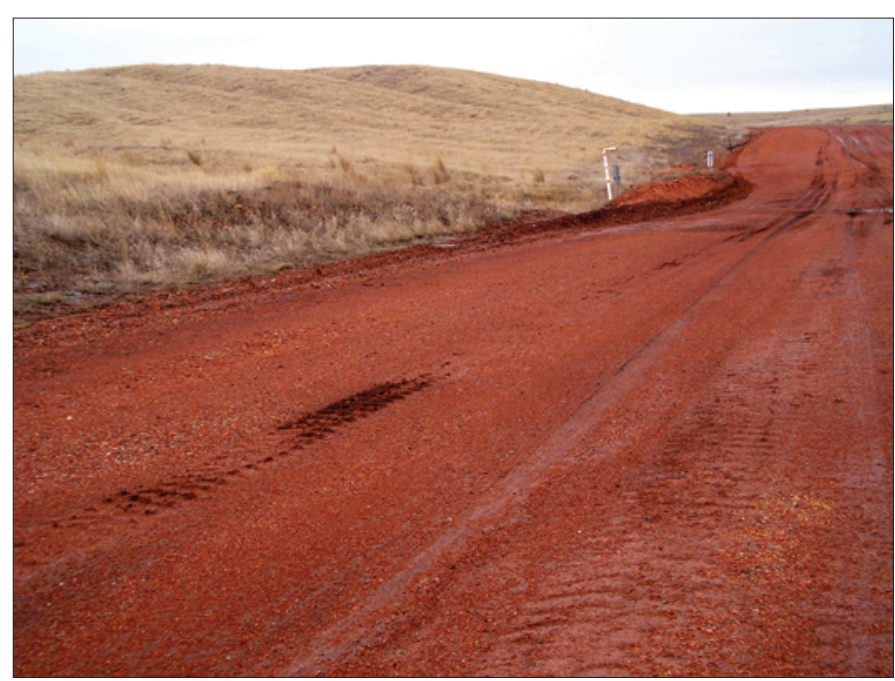

Figure 9. Surface strip mine area that has been reclaimed to grassland. Photograph by Paul Pierce, U.S. Geological Survey.

\section{Surface Facilities Required for USGS Surface-Mining Model}

Surface facilities are required at mine sites to provide a space for coal processing, storage, and shipping, as well as equipment maintenance, warehousing and supply, electrical substations, safety training, environmental and regulatory compliance activities, and administrative functions. Surface mine facilities usually include an administration building, a change room/bathhouse, large truck and small equipment maintenance shops, a warehouse, a laboratory building, an emergency first aid and training building, a utility building, a guard house, and assorted storage sheds and modules. Coal-handling equipment and structures include truck dump facilities, belt conveyors, coal breakers, sizing screens, product silo or pile, railcar loading tipple, and a railroad loop. Other items that accompany surface facilities include building furnishings and equipment, an electrical substation, land improvement, and stormwater diversion and capture facilities. The cost of mine site facility construction occurs during the preproduction phase of a mining operation, and certain worn-out items are replaced during production. All these expenses are included among capital costs in the USGS mining model. Actual surface mine facilities may vary based on mining conditions, practices, and philosophies. The design of model site facilities adopts regional practices when possible but relies chiefly on production rates, which are used to size equipment, personnel, and utility space, and to accommodate other personnel requirements. 


\section{Economic Modeling of USGS Surface Coal Mining Operations}

The USGS surface-mining model calculates the present value costs over the life of the mine from construction through closure and determines the amount of income necessary to conduct mining. In the following section, an economic evaluation is provided for a hypothetical mining example with the following provisions:

Given

- Coal bed with a thermal value of 8,800 British thermal units per pound $(\mathrm{Btu} / \mathrm{lb})$

- \$200 million for total capital investment

- \$85 million available for annual operating expenditures

- Coal recovery for a 20-year period

- Interest rate of 4 percent

Find

- Potential income to support mining investment

- Mining cost per ton

- Annual production rate

Although considerable detail is unknown in this example, the capital investment is assumed to be enough for constructing mine facilities and purchasing equipment. Also, additional funds are available to conduct yearly mining operations. The total income over the life of the mine to defray these costs as well as taxes levied on the project is calculated in table 2 . Costs and income are discounted to net present value to account for the time value of money. Each of the cash components included in the calculation (capital cost, depreciation, taxes, and operating costs) is detailed below.

\section{Capital Costs}

Capital costs for equipment, facilities, initial special items (for example, spare parts), and construction are applied in a current year, which is designated year 0 . Replacement of worn-out equipment and deteriorating facilities is equal to the economic asset life of 7 years in this example with capital reinvestment occurring every 7 years (years 0,7 , and 14).

Additional investment beyond the 14th year is unnecessary as it would exceed the economic life of the example.

The capital investment to equal $\$ 200$ million over the economic life of the hypothetical mine is split into three $\$ 85.6$ million discounted payments as determined through an algebraic calculation. Discounted dollar values are determined by the single-payment present-worth factor calculation (Pierce,
2019). The discounted cash value factors are multipliers of 1.0000 at year $0,0.7599$ at year 7 , and 0.5775 at year 14 . The net present cost of these assets is calculated as follows:

- Year 0: $\$ 85.6$ million $\times 1.0000=\$ 85.6$ million

- Year 7: $\$ 85.6$ million $\times 0.7599=\$ 65$ million

- Year 14: $\$ 85.6$ million $\times 0.5775=\$ 49.4$ million

- Total capital cost $=\$ 200$ million

The capital investment is complete at year 14 .

\section{Salvage and Reclamation Bond}

After the mine is closed, mining equipment can produce income by being sold as salvage. Minimal return on the cost of original machinery can often be expected, so the postmining value may be insignificant. Salvage may not be considered if income from selling the used mining equipment is less than the expected sale price of replacement equipment. In this hypothetical example, 1 year of economic and physical mine life remains at the end of the production period, and these assets could reasonably be considered unsalvageable as very little income is derived.

Likewise, the reclamation bond that is required by the U.S. Office of Surface Mining as a surety for returning mined land to its original or approved condition may also be disregarded in the economic model. The bond is posted during the preproduction phase and is not returned, all or in part, until after closure and the terms of the bond have been met. A period of 20-50 years could transpire before bond release, after which the present value would be greatly reduced (Pierce, 2019).

\section{Depreciation}

Depreciation is a method of reducing tax liability approved by the Internal Revenue Service. The cost of new capital items and replaced worn-out equipment and other items during production are depreciated to shield income from full taxation. Depreciation, by being allowed as a noncash disbursement to shield taxes, is both deducted from total income to determine the taxable income and added to total income to determine the cash flow. However, since the mining income is unknown, a reverse calculation reduces taxation by subtracting depreciation from cash flow to produce a net profit, which is added to the subsequent taxable income after an appropriate tax has been levied. Depreciation for equipment and other replaced items is adjusted to net present value using the singlepayment present-worth calculation (Pierce, 2019).

As described previously in the hypothetical example, the initial capital investment is $\$ 85.6$ million. The depreciable value using the straight-line method during years $1-7$ is one seventh of the capital investment or 14.3 percent ( $\$ 12.2$ million) per 
Table 2. Cost calculation for hypothetical surface mining operation to determine breakeven point between sales price and mining cost. [USGS, U.S. Geological Survey]

\begin{tabular}{lcl}
\hline \multicolumn{1}{c}{ Parameter } & $\begin{array}{c}\text { Amount (in millions of } \\
\text { dollars) }\end{array}$ & \\
\hline Total capital cost ${ }^{1}$ & 200 & Total capital investment during preproduction and postproduction phases \\
$=$ Cash flow & 200 & Income minus operating cost is equivalent to total investment. \\
+ Salvage & 0 & Unused equipment value discounted over mine life may yield little value \\
- Depletion & 0 & Tax calculation parameter; not generally used in USGS coal assessments \\
- Depreciation & 165.8 & Federal tax deduction of capital investment for tax burden calculations only \\
$=$ Net profit & 34.2 & Income remaining after taxes \\
+ Taxes & 34.2 & Combined Federal, State, and local taxes equals about 50 percent of net profits \\
$=$ Taxable income & 68.4 & Income remaining after acceptable tax deductions \\
+ Depreciation & 165.8 & Federal tax deduction of capital investment for tax burden calculations only \\
+ Operating cost & $1,154.2$ & Total tax-deductible cost of doing business throughout the production phase \\
$=$ Income & $1,388.4$ & Income required for total capital investment, taxes, and operating cost \\
- Tonnage & 115.8 million & Total mine life tonnage extracted and sold \\
$=$ Cost per ton & $\$ 12.00 /$ ton & Unit cost to extract tonnage and produce income \\
Price per ton ${ }^{2}$ & $\$ 12.00 /$ ton & Spot market sales price \\
Difference & $\mathbf{0}$ & Price per ton minus cost per ton; breakeven point at difference equals zero \\
\hline
\end{tabular}

${ }^{1}$ Contingency cost not included.

${ }^{2}$ As reported in Energy Information Administration (2020).

year. The second and third reinvestments extend this yearly depreciation over the 20-year economic life of the investment. The yearly present value is calculated by multiplying the depreciable amount by the discount rate (example: 0.9615 for year 1 ) for each year as follows:

- Year 1: $\$ 12.2$ million $\times 0.9615=\$ 11.7$ million

- Year 2: $\$ 12.2$ million $\times 0.9246=\$ 11.3$ million

- Years 3 and 4: discount rates of 0.8890 and 0.8548 , respectively

- Year 5: $\$ 12.2$ million $\times 0.8219=\$ 10$ million

- Years 6-14: discount rates declining from 0.7903 to 0.5775

- Year 15: $\$ 12.2$ million $\times 0.5553=\$ 6.8$ million

- Years 16-19: discount rates declining from 0.5339 to 0.4746

- Year 20: $\$ 12.2$ million $\times 0.4564=\$ 5.6$ million

The total depreciation net present value is the sum over 20 years or $\$ 165.8$ million (table 2).

\section{Taxes}

Taxes are direct charges against income that are levied by Federal, State, and county governments and municipalities. Federal taxes include an excise tax and an income tax. State taxes usually include taxation of corporate income, sales, use, motor fuel, and coal severance. County tax is levied for property. Tax rates vary widely by location. Cumulative rates may be as low as 22.08 percent for Wyoming and as high as 51.36 percent for Colorado (InfoMine, 2017).

In comparison, an average tax burden of 50 percent, ranging between 40 and 60 percent, has been convenient in conceptual estimates of mining income (Stermole, 1974). For the $\$ 200.0$ million capital cost example, the tax levy is $\$ 34.2$ million at a 50-percent tax rate. The tax calculation is as shown:

- Difference between cash flow and depreciation equals net profit.

$\$ 200.0$ million $-\$ 165.8$ million $=\$ 34.2$ million

- Net profit divided by tax percent equals taxable income.

$\$ 34.2$ million $\div(1-0.50)=\$ 68.4$ million

- Taxable income minus net profit equals tax.

$\$ 68.4$ million $-\$ 34.2$ million $=\$ 34.2$ million (table 2)

The tax due at a 40-percent rate would be $\$ 22.8$ million and, in comparison, $\$ 51.3$ million at a 60 -percent rate. 


\section{Operating Costs}

Operating costs are recurring ordinary expenses incurred during mining operations. These are annual uniform amounts in the surface-mining model occurring during the production phase. Equipment-operating costs include payments for electricity, grease, oil, tires, water, wire cables, and a multitude of other component items, as well as equipment maintenance. General mining supplies also incur operating costs that can include purchasing explosives for breaking and heaving overburden rock, as well as seeds, sprigs, and other vegetation for reclamation.

For this example, an operating cost of $\$ 85$ million is assumed to include $\$ 60.0$ million per year for equipment, \$20.0 million for personnel (salary and benefits), and \$5 million for supplies. Total operating cost for 20 years is $\$ 1,154.2$ million as calculated below:

- Net present value (NPV) factor of 13.5903 (20 years, 4-percent interest) using the uniform series present worth calculation (Pierce, 2019).

- Annual uniform cost multiplied by NPV factor equals total operating cost.

$\$ 85$ million $\times 13.5903=\$ 1,154.2$ million (table 2 )

\section{Income: Coal Sales Based on Market Price Calculation}

Coal is sold in large tonnage batches at varying prices, which are usually held as confidential by mining companies and are unavailable to the USGS for the purpose of conducting coal assessments. However, average prices are published by the U.S. Energy Information Administration (EIA) for five regions. These prices are short-lived as they are spot market reported and can vary weekly. A common denominator of EIA coal pricing is the thermal value in British thermal units per mass weight in pounds as follows (Energy Information Administration, 2020):

- Powder River Basin: 8,800 Btu/lb

- Uinta Basin: 11,700 Btu/lb

- Illinois Basin: 11,800 Btu/lb

- Central Appalachia Basin: 12,500 Btu/lb

- Northern Appalachia Basin: 13,000 Btu/lb

Corresponding average pricing for the Powder River Basin of Wyoming fluctuated from $\$ 11.45$ to $\$ 12.00$ per ton through early 2020.

The prices and thermal values reported by the EIA are used in the surface-mining model in direct proportion to the average thermal values of the coal beds in coal assessments. Coal having a value of $8,800 \mathrm{Btu} / \mathrm{lb}$ had a market price of $\$ 12.00$ per ton as reported for the week ending July 10, 2020 (Energy Information Administration, 2020) and is used in this assessment example.

\section{Coal Reserves}

The worth of coal reserves is determined through a comparison of the required income calculated from the discounted cash flow to the possible income calculated from the market price. The economic breakeven point occurs when these two income values are equal. They are equal when a total of 115.8 million tons are produced at a cost per ton equal to the $\$ 12.00$ price per ton (table 2).

In this example, a $\$ 200$ million capital investment is assumed to be sufficient to produce the required tonnage over the economic life of 20 years. However, a more detailed analysis may show that a $\$ 200$ million investment is insufficient to produce 115.8 million tons and, perhaps, could only produce 100.0 million tons. In that case, the corresponding cost of mining would be $\$ 13.88$ per ton, as calculated by dividing 100.0 million tons into $\$ 1,388.4$ million (table 2). The mining costs would be higher than the income that could be produced and the mining venture would be unprofitable. In this scenario, the coal resources would not be classified as reserves. If a $\$ 200$ million investment produces more than 115.8 million tons, the mining costs would be lower than the market price, and the venture would be profitable, which would change the classification from coal resources to coal reserves.

Fluctuations in market price and mining costs cause variations in the volume of coal resources that can be classified as coal reserves. A projection of different prices for reserve tonnage is most helpful in displaying the value of a coal field over time. Such a projection for a hypothetical case in which a reserve of 30 billion tons at a price of $\$ 12.00$ per ton would see an increase to 40 billion tons at $\$ 14.00$ and a decrease to 20 million tons at $\$ 10.00$. At $\$ 11.00$ per ton, the reserve base is 25 billion tons and at $\$ 11.45$, the reserve base is 27.25 billion tons.

\section{Future Coal Assessment Studies}

Thermal and other quality values for coal have not been historically considered for individual beds in previous USGS assessments. Considering thermal and other quality values for coal could produce a more robust assessment All coal beds within an assessment area - such as the Powder River Basin-were assigned the average of $8,800 \mathrm{Btu} / \mathrm{lb}$, as published by the Energy Information Administration. Data from Boyd (2011) provided average thermal values for mines within three areas of the Powder River Basin ranging from 8,000 to $8,500 \mathrm{Btu} / \mathrm{lb}$; from 8,800 to $8,850 \mathrm{Btu} / \mathrm{lb}$; and from 8,575 to $9,500 \mathrm{Btu} / \mathrm{lb}$. The proportional price per thermal value described previously for $8,800 \mathrm{Btu} / \mathrm{lb}$ at $\$ 12.00$ per ton would have a value of $\$ 10.90$ per ton at $8,000 \mathrm{Btu} / \mathrm{lb}$ and $\$ 12.95$ per ton at $9,500 \mathrm{Btu} / \mathrm{lb}$. Variable geologic conditions, coal quality, market conditions, and mining ability could be used to evaluate coal resources. 


\section{Summary}

In the U.S. Geological Survey (USGS) surface-mining model, surface coal mining using strip-mining methods is conceptually simulated from regional analogs. The mining model evaluates life-of-mine project costs including capital investment and operating expenses. Individual components are combined and evaluated in discounted net present value analyses and yield a single mining cost that is compared with a market or sales price.

An example of a hypothetical strip mine involving a $\$ 200$ million capital investment illustrates the mechanics of calculating the overall mining cost per ton of coal and its comparison to the market price as an index for determining reserves. An overall production rate of more than 115.8 million tons that is mined over 20 years is shown to have a mining cost that is equivalent to the market price of $\$ 12.00$ per ton of shipped coal.

A change in the reserve base is reflected by a declining price per ton over time. Price fluctuations are included in a coal assessment by developing a linear relationship between a range of prices and tonnage amounts through multiple evaluations of the USGS surface-mining model. More complex modeling could incorporate changes in the geological and market conditions, specifically details of coal deposition and quality, coal market dynamics, and mining operations.

\section{References Cited}

Boyd, J.T., 2011, Powder River Basin coal resource and cost study: John T. Boyd Company, report No. 3155.001, 84 p. [Prepared for Xcel Energy] at www.xcelenergy.com/ staticfiles/xe/Regulatory/Regulatory\%20PDFs/PSCo-2011/ 8-Roberts-Exhibit-No-MWR-1.pdf.
Energy Information Administration, 2020, Average weekly coal commodity spot prices: U.S. Energy Information Administration, accessed June 13, 2020, at www.eia.gov/coal/.

InfoMine, 2017, Taxes-U.S.: Spokane Valley, Wash., InfoMine USA, Inc., Cost Mine Division, Mining Cost Service, Section TA Taxes-U.S., p. 1-70.

Luppens, J.A., Rohrbacher, T.J., Osmonson, L.M., and Carter, M.D., 2009, Coal resource availability, recoverability, and economic evaluations in the United States-A summary, chap. D of Pierce, B.S., and Dennen, K.O., eds., The national coal resource assessment overview: U.S. Geological Survey Professional Paper 1625-F, 17 p.

Luppens, J.A., Scott, D.C., Haacke, J.E., Osmonson, L.M., Rohrbacher, T.J., and Ellis, M.S., 2008, Assessment of coal geology, resources, and reserves in the Gillette Coalfield, Powder River Basin, Wyoming: U.S. Geological Survey Open-File Report 2008-1202, 127 p.

Pierce, P.E., 2019, Economic analyses for U.S. Geological Survey coal basin assessments: U.S. Geological Survey Open-File Report 2019-1082, 33 p.

Stermole, F.J., 1974, Economic evaluation and investment decision methods 2nd ed.: Golden, Colo., Investment Evaluations Corporation, 449 p.

Thrush, P.W., 1968, A dictionary of mining, mineral, and related terms: Washington, D.C., U.S. Department of the Interior, Bureau of Mines, 1,269 p.

Wood, G.H., Jr., Kehn, T.M., Carter, M.D., and Culbertson, W.C., 1983, Coal resource classification system of the U.S. Geological Survey: U.S. Geological Survey Circular 891, 65 p. https://doi.org/10.3133/cir891. 


\section{Glossary}

Bench The horizontal step or floor along which coal, ore, stone, or overburden is worked ... a ledge that in open-pit mines and quarries, forms a single level of operation above which mineral or waste materials are excavated from a contiguous bank or bench face (Thrush, 1968).

Breakeven point Production level at which total cost equals revenue (Thrush, 1968).

British thermal unit (Btu) The quantity of heat required to raise the temperature of 1 pound of water 1-degree Fahrenheit $\left({ }^{\circ} \mathrm{F}\right)$ at or near its point of maximum density of $39.1^{\circ} \mathrm{F}$ (Wood and others, 1983).

Dragline A type of excavating equipment that casts a rope-hung bucket a considerable distance and then collects the dug material by pulling the bucket toward itself on the ground with a second rope before elevating the bucket and dumping the material on a spoil pile (Thrush, 1968).

Heave Upward movement of soil caused by expansion (Thrush, 1968).

Highwall The unexcavated face of exposed overburden and coal or ore in an opencast mine or the face or bank on the uphill side of a contour strip-mine excavation (Thrush, 1968).

Interburden Rock including coal, unconsolidated material, or both that lies between specified coal beds.

Overburden Rock including coal, unconsolidated material, or both that overlies a specified coalbed (Wood and others, 1983).
Recovery (recoverable) The percentage of coal mined from the original deposit (Thrush, 1968).

Reserves Economically recoverable coal that may be extracted considering environmental, legal, and technologic constraints (Wood and others, 1983).

Resources Naturally occurring coal deposits that are classified by their geological certainty and potential for economic viability (Wood and others, 1983).

Spoil The overburden or non-ore material removed in gaining access to the ore or mineral material in surface mining (Thrush, 1968). Also, "spoil pile" is used in this report to denote the resting place for spoil material.

Stemming Inert material packed between the explosive charge and the outer end of the blasthole.

Strip or surface mining (stripping) The extraction of coal by using surface mining methods such as area strip mining, contour strip mining, or open-pit mining. The overburden covering the coal is removed and the coal is extracted using power shovels, front-end loaders, or similar heavy equipment (Wood and others, 1983).

Topsoil Surface portion of the soil including the average plow depth or A-horizon if soil is deeper than the plow depth. The term is undefined as to actual depth or soil type (Thrush, 1968). 

Denver Publishing Service Center

For more information concerning the research in this report, contact the

Center Director, USGS Central Energy Resources Science Center Box 25046, Mail Stop 939

Denver, CO 80225

(303) 236-1647

Or visit the Central Energy Resources Science Center website at https://www.usgs.gov/centers/cersc 


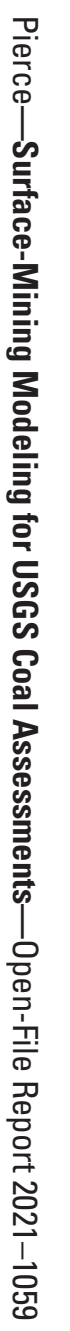

